MAGGIE O’NEILL (D)

Uniwersytet College Cork

\title{
BIOGRAPHICAL RESEARCH ON THE MOVE: THEORISING, EXPERIENCING, IMAGINING (THE CHICAGO SCHOOL RELOADED ${ }^{1}$ )
}

\begin{abstract}
This paper explores the importance of walking in biographical methods and critically reflects upon its theoretical, experiential and imaginative application 100 years after the publication of the The Polish Peasant in Europe and America. In doing so I ask how might walking as an 'arts based' approach to doing biographical research in collaborative and co-productive ways contribute to the conditions that support human well-being, re-ethicise social research and critically address social pathologies? In answering this question I focus upon the importance of critical theory and biographical sociology in understanding biography and history and propose that the experience of walking with another, conducting a WIBM, opens up the possibility of dialogue, listening as understanding, 'resonance', evokes trust and the potential for solidarity, as part of an ethics of listening. However, in doing so we must be mindful of the ethical implications of WIBM. Examples from walking biographical interviews illustrate the discussion.
\end{abstract}

Keywords: The Polish Peasant in Europe and America, walking, WIBM, biographical sociology, Chicago school of sociology

Professor, Department of Sociology and Criminology; e-mail: maggie.oneill@ucc.ie; https://orcid.org/0000-0002-4616-3388

1 With thanks to Brendan Flynn, NUI Galway for suggesting the title at a seminar chaired by Martin Javornicky in spring 2019. 


\section{INTRODUCTION}

This paper introduces, theorises and shares walking as a biographical method for conducting research that accesses the lived realities and cultures of individuals and groups, through time and in space, particularly in the context of the legacy of Chicago Sociology and the work of W.I Thomas and Znaniecki's [1958] The Polish Peasant in Europe and America, published in five volumes between 1918 and 1920. Walking was an essential part of the practice of sociologists in the Chicago School whilst undertaking first hand descriptions of life stories, through documenting the lived experiences of individuals and groups using systematic and in-depth ethnographic study and life story research.

The Walking Interview Biographical Method [O’Neill, Roberts 2019] has been influenced by the early Chicago School, the work of Robert Park, Thomas and Znaniecki as well as visual ethnography, art-making/walking artists, the critical theory of Walter Benjamin, and is very much rooted in the influence of Wright C. Mills [1970] Sociological Imagination, connecting the individual life to history, culture and structure. Walking in biographical research has a long and deeply embedded history, as an approach to doing sociological research with marginalised people in urban settings and is deeply influenced by the ethnographic research of Chicago Sociology. For example, as a former journalist Robert Park had 'tramped the streets in many cities, examining and reporting on social ills and he wanted to develop a deeper account and analysis of 'urban problems' [O'Neill, Roberts 2019: 52]. In Park's view, the city was not merely a physical collection of streets, buildings and institutions but a 'state of mind', part of the transmission of customs and traditions by its inhabitants. Students were encouraged to go out into the streets to observe and understand the city at first hand. The result of the Chicago sociologists interest in 'urban life were pioneering studies across a wide range of subjects' including homelessness, delinquents, organised crime, immigrant groups but also 'methodological developments, such as the life story/ history' ethnographic research, mapping and the collection of statistics to uncover 'situated meanings' [O’Neill, Roberts 2019: 52-53].

This paper explores the importance of walking in biographical methods and critically reflects upon its the theoretical, experiential and imaginative application 100 years after the publication of The Polish Peasant, building upon the innovative work of Thomas and Znaniecki [1958] around marginality, migration, personal and the importance of life history and biographical research. In doing so I ask, how might walking as an 'arts based' approach to doing biographical research in collaborative and co-productive ways extend biographical sociology and 
contribute to the conditions that support human well-being, re-ethicise social research and critically address social pathologies [Honneth 2009] such as homelessness.

In answering this question I focus first upon the importance of critical theory in understanding biography and history, the importance of working with and through the past [Adorno 2005, Schütze 1992] to raise awareness of how biographies and historical processes are intertwined and that in the experience of walking with another, experimenting with new biographical methods (WIBM) we might re-load (update) the methods of the early Chicago School. Conducting a WIBM, opens up the possibility of dialogue, listening as understanding and 'resonance' [Rosa 2019] that evokes trust and the potential for solidarity, as part of an ethics of listening. It also brings multiple forms of data together to understand lived lives in place.

The Walking Interview as a Biographical Method brings new perspectives to biographical narrative research by asking 'What are our imaginative spaces, our 'sensory scapes' - how biographically do we relate to our 'present', our immediate environment?' [O'Neill, Roberts 2019: xx] In developing and applying a WIBM we might use a variety of interpretive theories and schemas - narrative; phenomenology; textual and image analysis; artistic approaces and their interrelations [Roberts 2015; O’Neill et al 2015; O’Neill, Roberts 2019].

\section{THE MEANING OF WORKING THROUGH THE PAST: CRITICAL THEORETICAL UNDERSTANDING}

Biographical sociology is a method, par excellance for working through the past. For example, in 'The Meaning of Working through the Past,' Adorno [2005] argued that this 'modish slogan' - 'working through the past' does in fact mean its opposite, 'to close the books on the past, and if possible to remove it from memory' [Adorno 2005: 89]. In a very apt aphorism he says: 'in the house of the hangman one should not speak of the noose, otherwise one might seem to harbour resentment' [2005: 89]. Adorno is talking here about the impact of National socialism on the psyche, unconscious defensiveness against guilt and the desire therefore too to 'break free of the past' [2005: 89]. He goes onto argue, the 'ghost of what was so monstrous lives on' [2005: 89] and if we turn away from or do not seriously work 'upon the past' then (drawing upon a passage from Faust) 'its as good as if it never happened' [2005: 91]. In turn, we run the risk 'the destruction of memory;' and also, in Freud's terms, the return of the repressed. Moreover, as part of understanding the wider social context Adorno points to the 
individualising and responsibilising nature of advanced capitalism and the way it 'attributes to people everything that in fact is due to external conditions, so that in turn the conditions remain undisturbed.' This process can lead to alienation and 'peoples alienation from democracy reflects the self-alienation of society' [Adorno 1998: 93]. As Honneth [2009] identifies, the multiple approaches and work of those who connect with the Frankfurt School relate to the notion of social pathology and 'exploring the social causes of a pathology of human rationality' [Honneth 2009: viii]. Hence, for Adorno, the reality is that the:

oft-invoked working through the past has to this day been unsuccessful and has degenerated into its own caricature, and empty and cold forgetting, is due to the fact that the objective conditions of society that engendered fascism continue to exist [Adorno 2005: 98].

Making the past present and indeed withstanding 'the horror by having the strength to comprehend even the incomprehensible' is as important today as it was then, maybe even moreso given contemporary challenges: the UK exit from the European project; the rise of discourses of 'white supremacy,' a US president who separates and locks up migrants and their children, the rise and proliferation of walls and borders to keep out those on the move, in Bauman's terms the 'wasted lives' of current humanity. Honneth [2009: viiii] has called for a 'reactualization' of critical theory. I want to suggest that renewing biographical methodologies (the Chicago School reloaded/updated) that include walking as a way of doing biographical research could serve to re-ethicise social research, recover a sense of coherence and meaningfulness in collaborative and co-productive ways and at the same time uncover the non-identical underlying appearances, work through the past and preserve independent thinking.

Adorno goes on to state it is imperative, that sociology is strengthened in universities together with historical research of and in our own era. Adorno's work was concerned with: deconstructing identity thinking (the way unlike things appear as like); ideology as reification (uncovering the perceived naturalisation of that which is socially produced or constructed); defining the relationship between psychic, social and cultural processes and practices; the intersection of sociology, philosophy and aesthetics and illuminating the contradictory nature of social oppression. He also never gave up hope for the transformative possibilities of social critique, and particularly of the liberating potential of art and aesthetics.

The importance of and indeed meaning of seriously working through the past can be found in the work of biographical sociologists past and present, 
and particularly in The Polish Peasant ${ }^{2}$, the systematic, rigorous in depth ethnographies of the Chicago Sociology department, the pioneering work of Fritz Schütze's research and writing and other great biographical sociologists. As Kaźmierska [2018] states, whilst positivist and scientific research methods were coming to dominate Sociology in countries of the North, that marked a halt in the ascendancy of the in depth ethnographic method in Chicago Sociology, the auto/biographical method was being further developed by Znaniecki on his return from Chicago to Poland in 1920, around the concept of the 'humanistic coefficient' [Kaźmierska 2018: 394]. This is defined as: 'human behavior and attitudes can be comprehended and understood only if we have access to people's interpretations and individual perspectives' [Kaźmierska 2018: 394].

\section{THE POLISH PEASANT AND CHICAGO SOCIOLOGY}

Biographical sociology, emerged from the methodology used in The Polish Peasant, the analysis of official documents and statistics, personal letters, diaries as well as the autobiographical account of Wladek [Plummer 2001, Nilson 2008, Roberts 2006]. This firsthand account of life stories with a focus on meanings and interaction is a major contributor to symbolic interactionism. As Roberts [2006: 13] says 'sociological study was not to be confined to an ivory tower'. Methodologically, the systematic gathering and organisation of research data is a marker of The Polish Peasant but also of Chicago Sociology, as developed by Vivien Palmer ${ }^{3}$, a Chicago School Researcher in 1928 in her Field Studies in Sociology a student's manual. In Palmer's field guide we gain an understanding of the principles and practice of field research: the importance of a general back ground in the literature used; the collation of local data; and of life histories.

2 Published in 5 volumes between 1918 and 1920. Studying Polish migration to Chicago and those left behind.

3 An absent woman in the development of the history of Chicago Sociology, Vivien Palmer produced the field guide over a number of years and through the supervision of projects. The foreword to the field guide reads as follows: 'In the course of this and other studies Miss Palmer undertook the experiment of inducting students into the theory and practice of sociological field studies. She believed that the study of a local community, of an immigrant colony, or of some small group like a boys' or girls' club might be advantageously carried on in connection with work in the courses in sociology. She planned the work as indicated in this Manual in such a way that observations of group behavior in the field were timed to synchronize with the advance of the student in his reading of the textbook and in his class discussions. In this way he not only acquired some understanding of the principles and methods of research but he had at hand a growing fund of concrete materials to be organized and analyzed in terms of the concepts that he was studying.' 
Palmer describes and advises how the interview should start, proceed and close (yet remain unfinished). Research diaries and research maps were also included in the guide and data analysis.

Herbert Blumer's work, (the notion of 'sensitising concepts') and Anselm Strauss's stress on the need for sociology to study social interaction and indeed the vital importance of studying lives in process is an important legacy of Chicago Sociology alongside that of Mead and Shutz (phenomenology and symbolic interactionism). As Nilson [2008: 6] states 'a notion of self, and of life, as lived in time, with access to memories of experiences in the past and the willingness and ability to recount these in some present, is central in classical biographical research'. Moreover, as Bertaux and Kohli [quoted in Miller 2000] remind us: 'biographies are global constructions by which individuals constitute a defined present within the specific horizons of the past (retentions) and the future (pretentions)' [Bertaux, Kohli 1984: 222]. The Polish Peasant letters and Wladek's biography illustrate this and give value to subjective experience. As Wengraf, Bornat and Chamberlayne [2013] argue, the 'realism' of the Chicago school approach as a means of researching social processes and social change has entered and re-entered different European sociological traditions at different times; and the work of Schütze is central. 'His interest in suffering and disorderly social processes and, hence, his interest in 'trajectories' as a means of comparing responses to traumatic events' brings an important interactionist and psycho-social interpretation to biographical sociology and analysis [Wengraf et al 2013].

\section{FRITZ SCHÜTZE: LIFE TRAJECTORY AND WORKING THROUGH THE PAST}

In seeking to work through the past, understand collective guilt and the inability to mourn or repent (in contrast to psychological explanations) Fritz Schütze undertook a specifically sociological analysis of human behaviour, attitudes, interpretations and perspectives, influenced by Chicago Sociology and the work of Anselm Strauss in particular. He argues that biographical analysis 'which proceeds by means of narrative interviews' is especially helpful in working with psycho dynamic phenomena and the incapacity to mourn. Schütze developed a method which has becoming the signature method of biographical sociology; the interviewee is invited to give an 'extempore narrative on her or his life' and the interviewer is 'quiet except for signs of giving attention, listening and understanding' interrupting the flow of narrative only for clarification in 
understanding and when the story has ended a second phase is undertaken, following the narrative potentials of the main story, asking descriptive questions to better understand the narrative and then theoretical questions following the interviewee's 'own theorising' [Schütze 1992: 190].

In 'Pressure and Guilt: war experiences of a young German Soldier and their biographical implications' Schütze undertakes biographical research using a single case (interviews were undertaken with numerous people over a ten-year period, but this paper focuses upon one interview) and the biographical narrative interview method with an 'ideologically non-committed German'. The participant was a German soldier, Hermann, who was not committed to 'Nazi ideology' but 'active in the German war machinery' [Schütze 1992: 187]. Schütze found that the 'complex interlacing' of individual biographies and what he called 'collective mechanisms' is a feature of individual societal interaction and using the concept of 'trajectory' from Strauss [1985] he interpreted these complex intersections through concepts of 'collective social movement' and 'collective trajectory.' Schütze found that those who were not committed to the Nazi ideology 'witnessed the moral deterioration of the national collectivity of 'we, the Germans', but had also taken part in it as members of that collectivity who would neither protest nor fight against it' [Schütze 1992: 198] and were hence characterised as 'bystanders'. As Schütze [1992: 198] argues 'severely compromised in moral terms' the shock of the loss of their 'symbolic universe' hastened the repression or what he calls the 'fade out of their consciousness what had happened'. Thus, weakening their ability to mourn and to 'remember'. As Schütze found, memories returned later in life at often critical biographical moments, such as remembering feelings of compassion for those who suffered. 'The ability to mourn returned while working through their experiences theoretically and emotionally' [Schütze 1992: 198].

The blocking of long-term biographical action schemes and life plans and the necessity of dealing with life's immediacies, 'distracted from the loss of belief in one's own life and in some ultimate meaning of the world and one's destiny' [Schütze 1992: 198]. The 'moral deterioration of the collective trajectory', was also felt in 'sense making practices' leading to a 'loss of trust in life and the biographical energy related to it.' [Schütze 1992: 199]. Schütze talks us through the interview and analysis of Hermann's biography and how he was certainly not able to work through his experiences during or immediately after the war, but over time and in the context of various life circumstances and 'pressures', in critical moments he was able to work through some traumatising experiences within his life history. 
Hence, the importance of biographical sociology for working through the past and doing so in ways that connect theory and experience with praxis-with purposeful knowledge, for social justice. There is a crucial need for Biographical Sociology in the present era, to connect biography, to history, structure and culture, to work through the past and into the future as the sociological theory and biographical experiences discussed in this paper evidence.

\section{LIVED EXPERIENCE: A BIOGRAPHICAL REFLECTION}

The importance of critical theoretical understanding is, for me, connected both to my own biography as a sociologist, of working-class origin, a woman, and a feminist and the importance, indeed usefulness of our work as researchers and critical thinkers, that might serve the interests of social justice. As a biographical sociologist I came to life history research in 1989 as a way of better understanding and sharing the life stories and lived experiences of women. My first empirical study was on prostitution in Nottingham, a city in the East Midlands, UK. I was initially commissioned to undertake a three-month study that became a fiveyear project using participatory, ethnographic and life history methods, working with research participant rather than on or for them. The intention was to raise awareness and understanding of women's lives, with a view to influencing policy and practice, addressing sexual and social inequalities and women's experiences of poverty. At the time I was writing a PhD on Adorno's Aesthetics of Modernism and feminist aesthetics in particular and felt at home within the context of critical theory, western Marxism and the Frankfurt school's critique of society; and Adorno and Benjamin's hope in the transformative role of art. This 'committed' (Benjamin) approach to social research meant that my research methods and trajectory evolved from a commitment to critical theory, the transformative possibilities of art (and arts based research), ethnographic and biographical research methods (influenced by Chicago Sociology, the work of William Foote Whyte and especially the inspiration of fellow biographical researchers in ESA RN3) and participatory action research.

I considered my democratic subject-subject approach to doing research interviews and participant observation as sociological, feminist and ethnographic until I was introduced to participatory action research and the work of Orlando Fals Borda through Richard Harvey Brown. Here was a method that expressed not only a way of doing empirical research in democratic and respectful ways but a 'philosophy of life' that, for me, worked remarkably well with ethnographic and biographical methods. Participatory action research and participatory arts 
research was an approach to telling stories about people's lives that might make a difference and reach broader audiences as praxis (as purposeful knowledge) in the interests of social justice.

The importance of stories and storytelling was important, in understanding my own biographical trajectory, both within and outwith academia; my interpretation and understanding of Chicago School research and ethnographies; and the critical theoretical work of Benjamin and Adorno. In The Storyteller Benjamin tells us that storytelling plays a primary role in the household of humanity, in contrast to information - a fragment of a story of a life can tell us so much more than 100 pages of information about a life. 'A story...preserves and concentrates its strength and is capable of releasing it even after a long time' [Benjamin 1992: 90].

Biographical storytelling is a sensory, sensuous experience 'co-ordinating soul, hand and eye' [Benjamin 1992: 107]. At the same time for Benjamin, in order to counter the petrification of the imagination he stresses the need to revolutionise our image worlds [Benjamin 1992: 89-90]. He discusses the role of dialectical images and the politically emancipatory significance of the image - images for Weigel [1996] are not the object but the matrix and medium of his theoretical work. Benjamin's writings on the work of art and the art of storytelling has influenced our book, on the WIBM, and has inspired generations of storytellers. Benjamin was also a walker and a wanderer - he writes that Paris taught him the art of 'straying' [Benjamin 1986: 9].

At the ESA RN03 midterm conference at the University of Lodz in 2013, I suggested that biographical research narratives can heal, empower, challenge and transform our relationships to the past, present and future. They are also important psycho-socially, as narratives of self-making, fostering ethical communication, producing counter-hegemonic discourses and critical texts that may help to mobilise for change. At that conference I shared work in progress conducted with migrant mothers in the North East of England, using walking biographical research methods, to argue that ethno-mimetic process involved in using arts based, participatory and performative methods can help to create an ethical space - a reflective, safe space for dialogue, listening and understanding to emerge in ways that demand critical reflection; and that the combination of biographical and arts based methods within the research process can create a potential space, a holding space [or third space] that is creative, relational and potentially transformative for all those involved [O'Neill 2008, Jones 2006]. 


\section{WALKING AS BIOGRAPHICAL RESEARCH METHOD}

Building on more than a decade of walking based biographical research, Brian Roberts and I worked together on a book exploring and tracing the histories of walking as a method and developed the walking interview as a biographical method [O'Neil, Roberts 2019]. We were both influenced and inspired by artists who use walking as a method. I argue, with reference to recent research ${ }^{4}$ that through walking biographies we are able to get in touch with 'realities' and life trajectories [Schütze 1992, Kaźmierska 2018] in sensory and corporeal ways, that fosters 'reflexivity,' 'active listening' dignified representation, and critical reflection. But more than this, the opportunity to tell their stories, and view these stories and the small stories that make up their life stories, in different ways, from different angles, i.e., whilst walking in their neighborhoods or on a favorite walk, or a walk that is important to them, or whilst discussing the photographs taken on the walk, also enabled a deeper sense of 'understanding' [Bourdieu 1996] of their life experiences, for both narrators and researchers. This process/practice and the participatory foundations of the research also afforded a sense of 'trust' that I discuss later in relation to walking as a biographical method. This process, one could argue is foundational to working through the past.

Methodologically, the walking based research focuses upon three central themes: i) the importance of stories and storytelling; ii) re-presenting life stories in visual/artistic form [O'Neill 2008, Breckner 2010] using photography or working with artists to represent life stories in visual form (see: figure 1); iii) the transformative role and potential of walking in creating space for dialogue/understanding. Creating the space for storytelling also creates the space for dialogue and understanding that can connect biography to structure and history [Mills 1970] but also importantly to culture.

In reflecting upon the use of walking in biographical research, we might consider ways of knowing and understanding in biographical research and the potential for walking as part of the 'craft' of a biographical researcher. Hence, by introducing the WIBM, O'Neill and Roberts [2019] are suggesting that walking could be an additional means of conducting biographical research, on the move. In the next section I will explore the value and challenges of walking as part of the craft of biographical research, by drawing upon examples from

4 Leverhulme funded research Walking Borders, Risk and Belonging; Home Office funded research with migrant women in the North East of England and ESRC/NCRM funded research with migrant mothers, migrant girls and Mothers with no recourse to public funds in London (the latter with Umut Erel, Erene Kaptani and Tracey Reynolds). 
previous research and situating this within and indeed advancing the work of the early Chicago Sociologists discussed here and the work of Thomas and Znaniecki.

\section{WALKING METHODS IN SOCIAL RESEARCH}

There is, of course, a long tradition of walking in ethnographic and anthropological research, but not in biographical sociology. Horvath and Szakolczai [2018] conduct a genealogy of walking and write about walking, pilgrimage and settlement, Gros [2015] discusses the philosophy of walking. Rousseau described walking as an 'escape mechanism', the composer Eric Satie and Benjamin Brittan both write about the importance of walking to their practice as composers. Anthropologists Ingold and Lee [2008] reflect on the importance of walking in that 'social relations, are not enacted in situ but are paced out along the ground' as well as the importance in ethnographic research for understanding people's 'routes and mobilities'[Lee, Ingold 2006]. Here 'understanding' in the context and making of space and place is important to the authors.

As O'Neill and Roberts [2019] describe, Social Science research is increasingly 'on the move' with the rise of the mobilities 'paradigm' [Urry 2007] that focuses upon the mobile nature of our lives within a globalised world. The development of psychogeography (Nicholson) and mythogeography [Smith 2015], influenced by the 'flaneur' and urban wanderer, and undertaking to derive ${ }^{6}$ or drift [Debord 1956]. Drifting in cities, psycho geographers ask: how do places make us feel/ behave? What is the impact of urban architecture, street life on the individual. There is also a rise in walking as a way of interviewing - the 'go along method' [Pink 2007, Ferguson 2016, Irving 2010, Clark, Emmel 2010]. Sociologists Clark and Emmel [2010] in the UK discuss 'walking interviews' as a way of understanding how their participants 'create, maintain, and dissemble their networks, neighbourhoods, and communities.' For Pink [2007] it is important to conduct 'visual ethnography in/of movement' and 'how routes and mobilities are represented in local visual culture' for understanding 'how place and identities

5 Urry argues that the use of a 'mobilities paradigm' or 'mobilities turn' can draw attention to social relationships that are marked by 'diverse connections', often 'at a distance' and 'constituted through circulating entities' [Urry 2007: 46]. Moreover, he identifies five interdependent 'mobilities' that produce social life, forming and reforming 'its contours' both distant and proximate: corporeal travel; the physical movement of objects; imaginative travel; virtual travel; and communicative travel.

6 Inspired by Debord. 
are constituted' [Pink 2007]. Ferguson [2016] applies walking interviews or 'go along method' to explore social work practice; he shadowed social workers for 9 years to explore the mobile character of social work.

However, what I am suggesting here takes us beyond the notion of 'walking' as a method discussed by ethnographers and planners that helps us understand how space and place is made and used, how neighbourhoods are formed, reformed and sustained and instead argues for the creative application of walking as a biographical research method, as a deeply engaged, relational way of attuning to the life of another that evokes knowing and understanding through 'empathic' and 'embodied' learning. Through walking with another we can engage in an embodied/corporeal and convivial way of doing biographical research and attune to the narratives and lived experiences of research participants in ways that support biographical sociology and critical analysis. Moreover, it contributes to the 'advancement of biographical research in a time of uncertainty with its renewed interest in the social (re-)formation of the 'biographical'- the individual life within its social context' [O'Neill, Roberts 2019: 52].

As Solnit states 'walking shares with making and working that crucial element of engagement of the body and the mind with the world, of knowing the world through the body and the body through the world' [Solnit 2001: 29]. Thus it is a broad sensory and knowing experience which includes being or consciousness and phenomenological understanding in the making of who and what we are, for example in relation to self and identity formation as well as the contingent and shifting aspects of both; and in the process of walking with another and doing biographical research on the move it can enable inter-subjective and interactional understanding. Walking is, after all, integral to the practice and experience of everyday life [Pink 2008, Edensor 2010, O’Neill, Hubbard 2010, Myers 2010, Heddon, Turner 2010].

\section{WALKING BIOGRAPHIES: UNDERSTANDING, ATTUNEMENT AND TRUST, OR TOWARDS AN ETHICS OF LISTENING}

Biographical research has relied almost extensively on talk, the oral history, the interview as well as some 'personal materials' such as letters and diaries to understand 'the individual life within its social context' [Roberts 2002: 3]. Indeed, 'the intent of biographical research in its various guises is to collect and interpret the lives of others as part of human understanding' [Roberts 2002: 15]. In answering how, Bourdieu's account of understanding is helpful. 
Bourdieu [2000: 608] writes about the craft of social research, the importance of reflexivity, of a sociological 'feel' or 'eye' that allows the researcher to 'perceive and monitor on the spot as the interview is actually taking place, the effects of the social structure within which it is occurring' as well as setting up a relationship that involves active listening [see also: Fromm 2009, Rogers 1980] that combines a 'total availability' to the participant as well as 'submission to the singularity' of the [life] story being told. Such reflexivity can become a 'double socioanalysis' where both the researcher and narrator are involved in creative thinking, reflecting and learning and without cancelling the social distance between them the participants can 'be themselves' and the researcher can 'mentally put themselves' in the place of the participant, to 'take their part' not to project themselves onto the other. Rather through 'forgetfulness of self' understanding involves the researcher giving 'oneself a generic and genetic comprehension' of who the participants are based upon a 'grasp' of their life circumstances as well as the social mechanisms 'that affect the entire category to which the individual belongs and grasp the conditions, inseparably psychological and social, associated with a given position and trajectory in social space. Against the old distinction made by Wilhelm Dilthey, we must posit that understanding and explaining are one' [Bourdieu 2000: 613].

Understanding involves the art of listening [Fromm 2009]. Active listening demonstrates being open to the other, being non-judgmental. Active listening also involves having and demonstrating respect and recognition, not in a tokenistic way, but in a deeply engaged way [see: Schütze 1992, Kaźmierska 2018, Miller 2005, Berteaux, Kohli 1984]. Active listening can create empathy and build trust as a relational good. Committed to taking an active listening approach, fostering subject-subject relations in biographical walking interviews, and by working collaboratively with others in arts based workshops, trust emerges as a disposition and an orientation. Since 'human beings become increasingly trustworthy once they feel at a deep level that their subjective experience is both respected and progressively understood' [Thorne 1992: 26]. We act relationally and reflexively and for Archer [2015] relational goods are produced through trust and reciprocity.

Hence, in creating the space for storytelling, the biographical researcher also creates the space for dialogue, listening and understanding that can connect biography to culture, structure and history [Mills 2000]. As described earlier, the main skill involved in the 'craft' of biographical research involves conducting the 'narrative interview' [Schütze 1992]. Riemann [2003] describes the 'narrative interview' as 'firmly grounded in members' everyday competencies 
to narrate their own experiences' and it is important to let the interviewees tell their experiences without, as far as possible, interference and 'elicit narratives of experience' [Wengraf 2001, see also: Miller 2000, Rosenthal 2011, FischerRosenthal 2002, Fischer 2012].

Sparkes [2004, 2015] discusses how in his life history research he 'feels' his way into and out of analysis and 'experiences' the embodied nature of the narrative work undertaken with sportsmen with spinal injuries. The biographical interview facilitates, to varying degrees, a discursive, relational and reflective space in which feelings matter and can act as a guide. Drawing upon Witkin [1974] I have described this process as involving subjective-reflexive feeling [O'Neill 2001, 2008].

Biographical approaches have developed from a focus upon a single 'story' (or group of 'stories'), a 'life story', to include autobiographical, secondary and archival research [see: Roberts 2002] and analysis - as well as multi-media, arts based creative and multi-sensory, multi-modal methods [see: Given 2015, Miller 2015, Haaken 2015]. As part of human understanding biographical research helps people to make sense of what has been and what is happening in their lives, cultures, communities and societies. Roberts [2002] documents how a surge of interest in biographical methods can be attributed to a variety of factors: a developing disillusionment with static approaches to data collection; a growing interest in the life course; an increased concern with 'lived experience' and how best to express and reveal it. Biographical research enables 'understanding' through listening and 'attunement' [Scheff 2006].

For Miller [2000] the importance of biographical sociology in these times, is not that it is a method for doing social research on life stories but that 'biography is not a mere sociological product or research tool; it is primarily a social phenomenon that must be seen as a fundamental constituent of sociality' [Chanfrault-Duchet 1995: 212]. And, 'As people live their lives, they continuously are doing 'biographical work'; that is, as they move through life they must construct and reconstruct their self-view in response to an ever-changing society.' [Miller 2000: 3]. 'Biographical work ...is the symbolic process by which individuals achieve this balance by reflexively structuring their experiences and activities. It enables them to practically orient themselves, while dealing with events ongoingly as they go through life' [Fischer-Rosenthal 1995: 261].

Research methodologies that create spaces for the voices and images of the marginalised, through biographical methods can serve not only to raise awareness, 
challenge stereotypes and hegemonic practices, but can produce critical texts that may mobilize and create 'real' change. Moreover, representing life stories in visual form can make visible hopes, ideas and experiences and provide a richer understanding of the complexity of lived experience and challenge us to think differently, to reach a wider understanding and a wider audience. In biographical research with newly arrived Bosnian community to the East Midlands in 1999 I worked with artists to help research participants tell their life stories in visual form. The art works that resulted were powerful visually and facilitated a space and opportunity for 'understanding'.

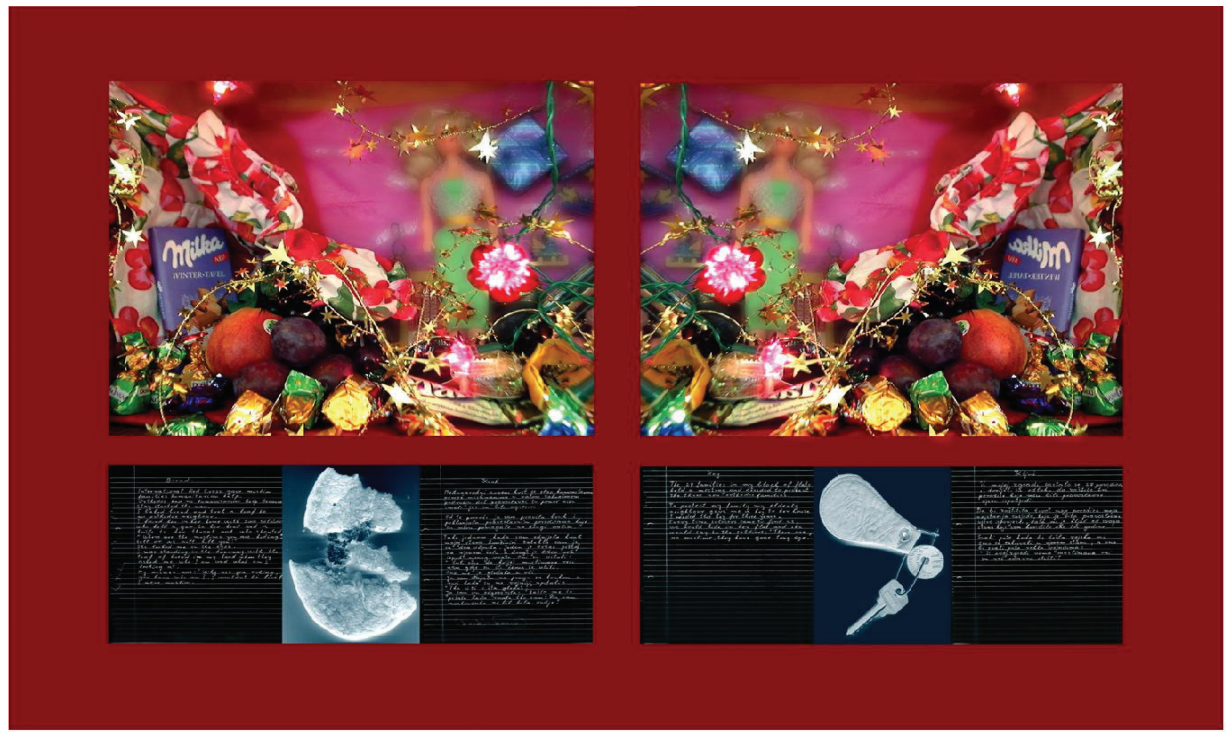

FIGURE 1. Good neighbour. Image: Fahira Hasedic and Karen Fraser

The text relating to the key states:

The 28 families in my block of flats held a meeting and decided to protect the three non-orthodox families. To protect my family my elderly neighbour gave me a key to her house. I needed this for three years. Every time soldiers came to find us, we would hide in her flat and she would say to the soldiers: 'There are no Muslims, they have gone long ago.'

Here, biographical work re-presented poetically, visually as well as textually can help to illuminate the necessary mediation of autonomous individuality and collective responsibility and the care shown by her orthodox neighbours. Buck 
Morss [2004: 10] states that the 'significance of the image, now understood not merely as representing the real, but as producing a new reality, a sur-reality.' In this sense images produced in biographical research are constitutive, they bring something new into the world rather than simply representing (in mimetic fashion) what is already there.

\section{WALKING, SENSING, VISUALIZING}

As a method for conducting biographical research walking has much to recommend it, especially when combined with visual and participatory forms of doing research. Walking can help articulate the material, phenomenological, lived, embodied and imagined yet transitory sense of lived lives as well as giving priority to walking and thinking as 'body and image-space' [Weigel 1996] for 'modulating alienation' as well as 'that crucial element of engagement of the body and the mind with the world, of knowing the world through the body and the body through the world' [Solnit 2001: 29].

The 'inter-textuality' between art and biographical approaches as well as individual and collective biographies can extend the relational and connective aspects of biographical research, capture the sensory, embodied sense of our social lives/lived experiences and open up dialogue and the transformative role of biography/art/creativity on many levels, including the potential impact on policy and practice, through the application of biographical research.

Combining the sensory experience of storytelling with sensory immediacy of the visual/performative experience of walking, opens up a discursive space where embodied knowledge and experience are shared. As described earlier, such multi-sensory ways of knowing (experienced through walking) focus attention on the sensory, dimensions of lived experience - and the relationship between the visual and other senses.

A biographical walk with Faye, a woman living in direct access housing provision in an English city, reinforced the experience of walking in biographical research as relational, revelatory, sensory and absolutely embodied. Invited to conduct a 'walkshop' as part of Open Clasp, (a feminist theatre company) residency in the hostel, I asked women to draw a map of an everyday walk, or, using artist Misha Myers [2007] practice, a walk from a place you call home to a special place. Faye drew an everyday route 'from the hostel, through the redlight area, to the town centre, past tent city' [Faye in: O'Neill, McHugh 2017) and to the park (her special place), where we sat and drank 'posh' coffee. 


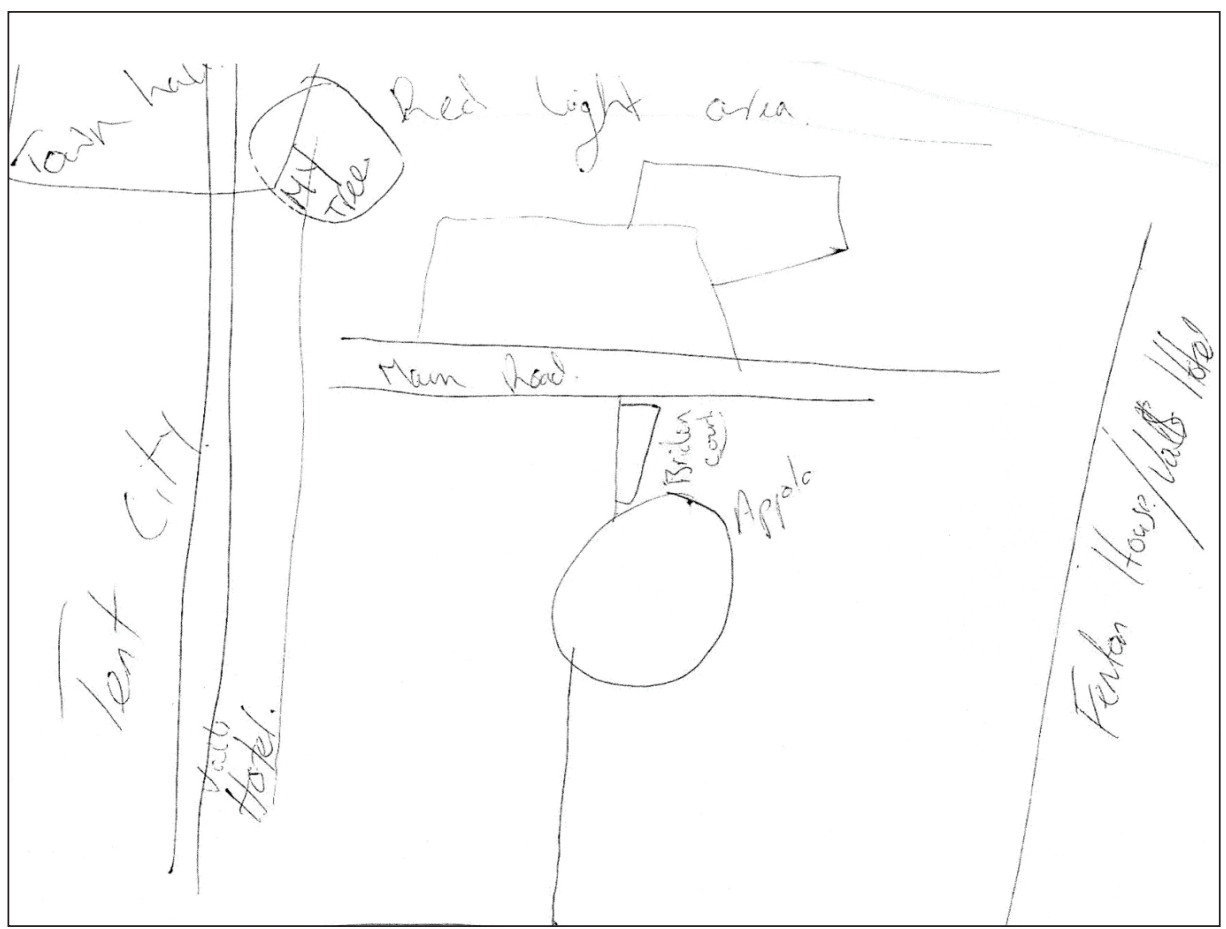

FIGURE 2. Faye's map

During the mapping exercise we attuned to Faye's story (she talked us through her route before walking with us) her experiences and reflections on border spaces and places, identified along the route, the borders and margins of the city, through alleyways, underpasses, back spaces, the red light area where she sometimes works, past her favourite tree, where she asks permission to walk over its 'leg' (roots), past tent city and into the gardens of the park. During the walk and at a roundabout Faye stops to take a photograph and says:

'This is an important focal point to the entire story really, each turn off represents none times out of ten what a person in this (kind of) life. What they are doing, grafting, using, scoring. From here you can go to DA, you can go and buy drugs, you can go to the red light area, you can go to tent city, so this is like the middle bit from here, that roundabout really does represent something in each direction'.

During the walk, the conversation was recorded on a digital sound recorder and Faye took photographs of landmarks and places that she wanted to talk 
about, that had meaning to her biography. We learned that the first time she did sex work was by accident, she was fifteen and a man asked her to sit in his car, just that, to sit in his car, and then he gave her twenty pounds, which she used to buy batteries for her Walkman. At the end of the walk, over (posh) coffee in the park, Faye told us more about her life and her aspiration 'her wants and desire to change' to live what she called 'a good and happy life against the tide of her life' [O'Neill, McHugh 2017]. Faye liked old soul music and she sang us a few lines from her favourite song. We connected in a sensory way to her bravery and resilience and search for belonging as feeling/being 'in place' or 'at home' albeit 'on the move'. Back at the hostel, Faye curated her images around her map and shared her walking biography with us and other women resident in the hostel, writing her personal meaning on the back of each photograph, before placing it near the route map (figure 2 and figure 3 ).

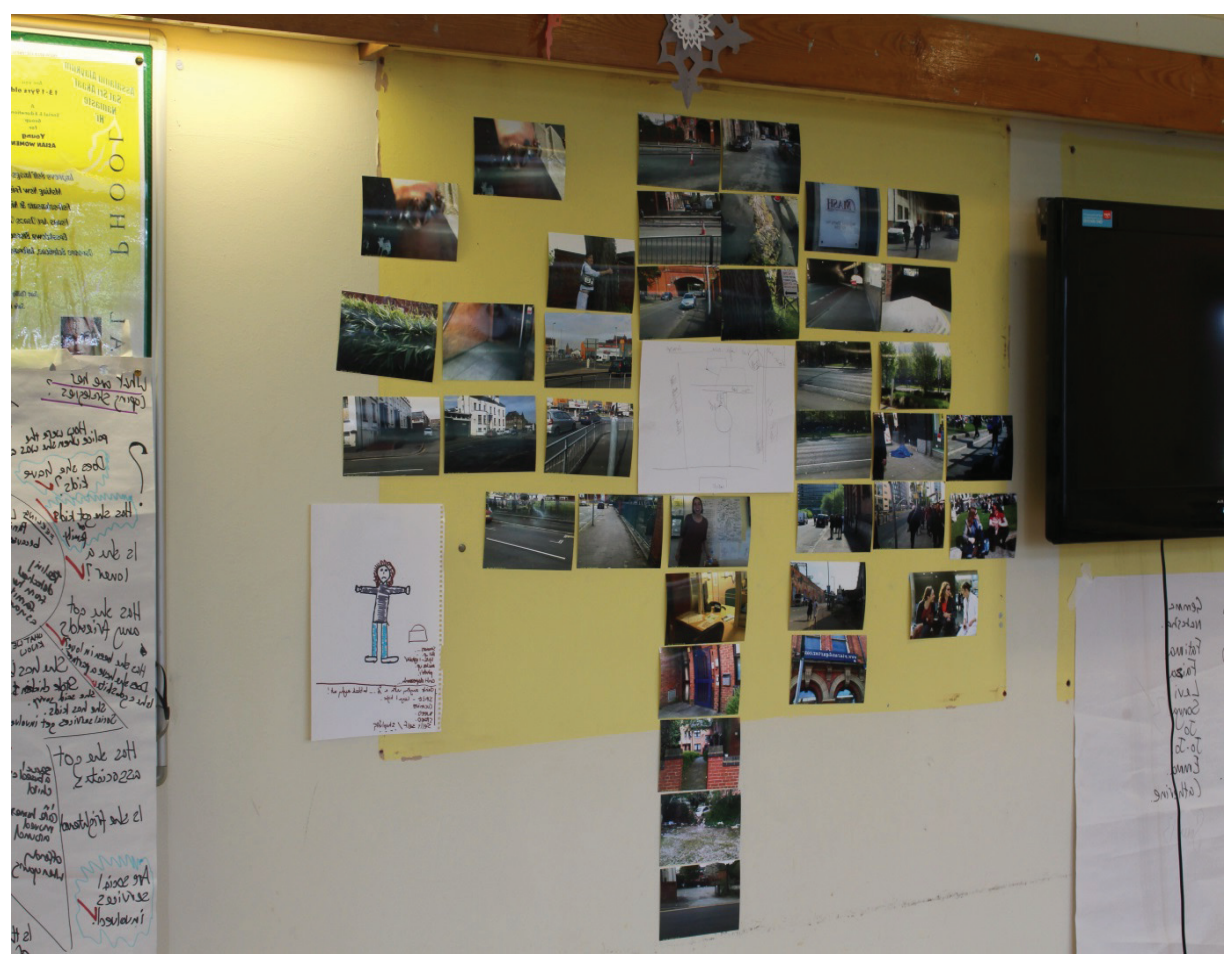

FIGURE 3. Curated WIBM: Mapping and visualising 
What biographical scholars know is that narratives are relational and reflective, and they involve the performative. John Given, has written about the narrative construction of identity and how this is emplaced and embodied [Given 2015]. At our RSN 3 midterm conference in Cracow and later still, Heinze and Hornung et al. [2013] in a conference by the German Biographical Sociology discussed the connections between visual sociology, digital and performing arts, to enrich the potential of biographical sociology and help us to think across borders in new ways. I have previously called the process of the inter-relationship between ethnographic, biographical work and arts practice as ethno-mimesis and the outputs of the collaboration as 'feeling forms' [O'Neill 2001].

To summarise, walking as a biographical research method is a powerful route to understanding the lives and experiences of others. As the walk with Faye shows, walking is not just what we do to get from ' $a$ ' to ' $b$ ' but integral to our perception of an environment. Taking a walk with someone can be a powerful way of doing a biographical interview, communicating about the meaning of experiences, the past in the present. One can become 'attuned' to another, connecting in a lived embodied way with the feelings and corporeality of another, on the move in the natural and social environment [see: O'Neill, Roberts 2018: 251-259]. Scheff [2006] argues that the emotional/relational world is important 'since it constitutes the moment-by-moment texture of our lives' and 'it is intimately linked to the larger world'. Using Stern's concept of 'attunement' he refers to the cognitive, connectivity between people. 'In my usage, the word attuned or attunement alone, unqualified, will refer to a balancing of the viewpoints of self and other, neither engulfed (too close) nor isolated (too far)' [Scheff 2006: 2]. The physical embodied process of walking, remembering, sensing - attuning - is constitutive and the relational shared process opens up a discursive space that is also a reflective space.

In this space for dialogue and reflection embodied knowledge, experience and memories can be shared [O'Neill, Hubbard 2010; Pink et al. 2010]. Walking is also 'performative' it enables relational work to be undertaken that involves the performing, sensing body [Lammer 2012]. Walking together can advance connection, dialogue, active listening and understanding that might create a space for/ raise awareness of reflection and action. In this way walking is an embodied research practice and process that is relational, discursive and reflective. Importantly, it is also sensory and can be multi-modal - and facilities multiple modalities of experiences that can be shared. This Walking Interview as Biographical Method advances the multi-modal methods used by Thomas and Znaniecki [1958] and members of the Chicago School of Sociology for the twenty first century, by 
combining visual and kinaesthetic methods - a methods on the move; advancing the participant observer methods by being sensitive to the narrative, the conversation and the 'scene' in a 'walking dialogue' [O'Neill, Roberts 2019].

\section{ETHICAL IMPLICATIONS}

In connecting walking and talking about life histories O'Neill and Roberts [2019] remind us that we do need to be mindful of the challenges as well as the 'added value' over the 'standard' biographical or narrative interview method. Walking might raise all kinds of emotions e.g. memories of home for migrants - which may be good but also distressing [see: O'Neill, Roberts 2019, O'Neill 2010, O'Neill, Hubbard 2010 for a fuller discussion]. The full extent of the ethical implications will unfold over time, as this research approach is taken up by biographical researchers; but ethics need to be at the heart of the WIBM. On the one hand the suggestion here is that walking biographical research can re-ethicise social research by contributing to the conditions that support human well-being and biographical research can critically address and uncover social pathologies, as an ethics of listening. For example, freeing biographical research from the constraints of 'structurings' of place -the lounge, kitchen, café or even office, with situational authority in the hands of the research participant, there is the opportunity for a more subject-subject dialogue between researcher and participant, evoking inter-subjective mutual recognition and storytelling (a biographical interview) of the life, lived experience within the social context [see: O'Neill, Roberts 2019]. Without walking with Faye we might never have known about how the front door of the hostel makes her feel, the importance of the tree she crosses to go to work in the underpasses and liminal spaces of the city's red light area. We may not have learnt about how her biographical routes into selling sex, nor how she feels about the rising homelessness in the city.

On the other we need to be mindful of the ethical risks, for example, walking 'side by side', the rhythm of walking and the attunement and resonance created may lead narrators to disclose that which they may not have done in the office, of coffee lounge. I am thinking here about examples of circumstances or situations of risk and harm that take us beyond unintended disclosure that can be a 'valuable analytic resource'? As Kaźmierska [2018] discusses there is a need to adapt

7 Thanks to the anonymous reviewer who in asking for clarity around the meaning of such spontaneous disclosure suggests that of course narratives which are strictly and strategically controlled by the interviewee can lead to dubious data and I agree. An ethical sensibility towards a walking interview must be taken (as in a biographical interview conducted in a kitchen, café) that 
and rethink ethics to advances in biographical methods 'as part of a professional ethic construed as the systematic exploration of the methodology used by biographical researchers and the need for constant reflection on the research process' [Kaźmierska 2018: 408]. Kaźmierska's [2018] analysis provides guidance here in strongly arguing that we need to be cognizant of the 'illusory expectation' that informed consent 'removes ethical dilemmas'. As she states we need ethical codes but using ethical regulations should not lead to a:

'paradox in which we will feel protected by documents and not obliged to respect the social rules of interaction or to remember that we are engaged in a very human practice: namely, that the research situation in qualitative studies, and especially in the biographical approach, is above all a matter of meeting with another person'. Kaźmierska [2018: 409]

Ethics are not an end stop or an event but a process and an important aspect of the training of biographical researchers is in developing an ethical sensibility that involves constant reflection through a thinking, feeling practice, that also involves 'understanding' [Bourdieu 1996].

The challenges for the biographical researcher are many, biographical and walking research is time and labour intensive, analysing images, and fieldnote reflections as well as the narrative interview also mean that analysis is a lengthy process. The tension between project and process time [Oili-Helen Ylijoko 2011] and the impact of acceleration of academic life [Rosa 2015, Vostal 2015] and the reduction of time to process (before we need to generate funding for the next project) is a constant challenge for biographical and participatory researchers.

Doing biographical research through walking with another in and through their social worlds can help us to access a richer understanding of complex lives and experiences that may well be otherwise unspoken or 'unsayable' especially for the marginalised. As argued earlier walking and art making creates a space for dialogue, reflection and understanding, that can be shared across a broad audience (for example see: figure 2). Indeed, it may enable a 'radical democratic imaginary' that challenges exclusionary discourses and connects to more relational ways of providing space for the voices of others and in doing so promotes social justice. As Miller [2000] said as people move through their lives they are constantly doing 'biographical work' that is 'they must construct and reconstruct their self-view in response to an ever changing society..reflexively structuring their experiences and activities' [2000: 156].

carefully handles and balances the interview and does sufficient justice to the legitimate interests and integrity of the interviewee. 


\section{WALKING INTERVIEW AS A BIOGRAPHICAL METHOD: CHICAGO SCHOOL RELOADED}

The WIBM offers a renewed social focus on the Biographical Method within the context of Chicago Sociology and the legacy of The Polish Peasant and contributes to the methodological advancement of biographical research, at a time of great uncertainty. The examples shared above illustrate the relational, sensory, kinaesthetic, democratic, participatory-connection afforded by walking in a subjectsubject relationship. When walking (side by side) with Faye [O'Neill, McHugh 2017], she guides the walk and the narrative evidences inter-subjective mutual recognition. The narrative and the images together enable us to discover and feel the multiple modalities of her experience. The physical process of walking, remembering, seeing, listening, feeling and attuning is inherently performative.

The example of Faye's walk, illustrates a creative application of Biographical Research through visualising, performing biographies and multi-sensory ways of knowing. Walking with another opens up a dialogue and a space where embodied knowledge, experience and memories can be shared. Walking is relational in enabling multi-sensory experience and affective multi-sensory ways of knowing; attuning to another also focuses attention on the sensory, dimensions of lived experience - and the relationship between the visual and other senses, the noise, smells, weather conditions and aesthetics of the surroundings.

Walking methods (and biographical research in general) involves a great deal of emotional labour - this is relational work. The impact of walking biographical methods is that they create knowledge and understanding through connection and collaboration, as evidenced in the walk with Faye. One could argue that walking as biographical method opens dialogue about the transformative role of creative and innovative methods on many levels.

I have argued in this chapter that through arts based biographical methods such as walking we are able to get in touch with our 'realities' that enable a critical recovery of history - via peripatetic/kinaesthetic ways of knowing and understanding. I have highlighted the importance in social research of innovative ways of doing biographical research in order foster dialogue, understanding, reflection and action on the world in order to transform it. Walking as biographical method ultimately involves the role of the imagination. Influenced by Chicago Sociology, the critical theory of Walter Benjamin (walking/images and storytelling) walking arts practice and participatory methods advance biographical methods in a number of ways. Conducting walking biographical interviews is a dynamic, 
mobile, relational, embodied process and practice that: involves walking with, 'side by side', opens a space for dialogue; offers an attention to space and place (as well as time) that involves the role of memory, both voluntary and involuntary [see: Benjamin 1985, 1992]. Taken together walking as a biographical research method impacts upon understanding and experiencing the conditions that support human well-being, that may also serve to re-ethicise social research as part of an ethics of listening and understanding, whilst also evoking solidarity in critically addressing and critiquing contemporary social pathologies.

\section{BIBLIOGRAPHY}

Adorno Theodor Wiesengrund. 2005[1969]. Critical models: Interventions and catchwords. New York: Columbia University Press

Archer Margaret. 2015. The relational subject. Cambridge: Cambridge University Press.

Bauman Zygmunt. 2004. Wasted lives: Modernity and its outcasts. Cambridge: Polity Press.

Benjamin Walter. 1985. One way street and other writings. trans. E. Jephcott, K. Shorter. London: Verso.

Benjamin Walter. 1992. The storyteller. In: Illuminations, H. Arendt (ed.), trans. H. Zohn, 83-111. London: Fontana Press.

Bertaux Daniel, Martin Kohli. 1984. "The life story approach: A continental view". Annual Review of Sociology 10: 215-237.

Bourdieu Peter. 1996. "Understanding". Theory, Culture and Society 13(2): 17-39.

Clark Andrew, Nick Emmel. 2010. Using walking interviews. Manchester: Morgan Centre, University of Manchester.

Edensor Timothy. 2010. "Walking in rhythms: Place, regulation, style and the flow of experience”. Visual Studies 25(1): 46-58.

Fals Borda Orlando. 1983. Knowledge and people's power: Lessons with peasants in Nicaragua, Mexico and Colombia. New York: New Horizons Press.

Fals Borda Orlando. 1987. "The application of participatory action research in Latin America". International Sociology 2: 329.

Ferguson Harry. 2016. "Professional helping as negotiation in motion: social work as work on the move". Applied Mobilities 1(2): 193-206, http://dx.doi.org/10.1080/23800127.2016. 1247523 .

Fromm Erich. 1998. The art of listening. London: Continuum.

Gros Frederic. 2015. The philosophy of walking London: Verso.

Heddon Deirdre (Dee), Cathy Turner. 2010. "Walking women: Interviews with artists on the move". Performance Research 15(4) 14-22.

Honneth Axel. 2009. Pathologies of reason. On the legacy of critical theory. New York: Columbia University Press.

Horvath Agnes, Arpad Szakolczai. 2018. Walking in the void. London: Routledge.

Irving Andrew. 2010. "Dangerous substances and visible evidence: Tears, blood, alcohol, pills". Visual Studies 25(1): 24-35. 
Ingold Tim, Jo Lee-Vergunst. 2008. Ways of walking: Ethnography and practice on foot. Aldershot: Ashgate.

Jones Kip. 2006. "A biographic researcher in pursuit of an aesthetic: The use of arts-based (re) presentations in 'performative' dissemination of life stories". Qualitative Sociology Review, II (1): 66-85.

Kaźmierska Kaja. 2018. "Doing biographical research-ethical concerns in changing social contexts". Polish Sociological Review 3(203): 393-491.

Mills Wright C. 1970. The sociological imagination. Harmondsworth: Penguin.

Miller Robert. (ed.). 2000. Researching life stories and family histories. London: Sage.

Miller Robert. 2005. Biographical research methods. (volumes 1-4), London: Sage.

Myers Misha. 2006. "Along the way: Situation-responsive participation and education". The International Journal of the Arts In Society 1(2): 1-6.

Myers Misha. 2010. "Walk with me, talk with me: The art of conversive wayfinding". Visual Studies 26(1): 50-68.

O'Neill Maggie. 2008. "Transnational refugees: The transformative role of art". Forum Qualitative Sozialforschung/Forum: Qualitative Social Research [S.1.] 9(2) Available at: http:// www.qualitative-research.net/index.php/fqs/article/view/403 [Accessed: 16.08.2018].

O’Neill Maggie, Philip Stenning. 2013. Walking biographies and innovations in visual and participatory methods: Community, politics and resistance in Downtown East Side Vancouver, In: Medialization of auto/biographies: Different forms and their communicative contexts, C. Heinz, G. Hornung (eds.), Hamburg: UVK.

O’Neill Maggie, Phil Hubbard. 2010. "Walking, sensing, belonging: Ethno-mimesis as performative praxis". Visual Studies 25(1): 46-58.

O'Neill Maggie, Brian Roberts, Andrew Sparkes. (eds.). 2015. Advances in biographical research: Creative applications. Abingdon, Oxon: Routledge.

O'Neill Maggie, Brian Roberts. 2019. Walking methods: Research on the move. London: Routledge.

O'Neill Maggie, Catrina McHugh. 2017. "Walking with Faye from a direct access hostel to her special place in the city: Walking and body image space". Journal of Social Work Practice. Psychotherapeutic Approaches in Health, Welfare and the Community 3(2017). (Special Issue on Seeing with the Mind's Eye: Social Work and the Visual Imagination, Guest Editors: L. Froggett, J. Manley, M. Smith, A. Roy).

Palmer Vivien. 1928. Field studies in sociology. A student's manual. Chicago: The University of Chicago Press.

Pink Sarah. 2007. "Walking with video". Visual Studies. 22(3): 240-52.

Pink Sarah. 2008. "Mobilising visual ethnography: Making routes, making place and making images". Forum Qualitative Sozialforschung/Forum: Qualitative Social Research 9(3), Art. 36, http://nbn-resolving.de/urn:nbn:de:0114-fqs0803362.

Plummer Ken. 2001. Document of life 2: An invitation to a critical humanism. London: Sage.

Revisited, Aldershot: Ashgate.

Riemann Gerhard. 2003. "A joint project against the backdrop of a research tradition: An introduction to 'Doing biographical research'”. Forum Qualitative Sozialforschung/Forum: Qualitative Social Research, 4(3), Art. 18, http://nbn-resolving.de/urn:nbn:de:0114-fqs0303185. [Accessed 14.08.2018].

Reissman Catherine K. 2008. Narrative methods for the human sciences. London: Sage.

Roberts Brian. 2002. Biographical research. Buckingham: OU. 
Roberts Brian. 2006. Micro social theory. Basingstoke: Palgrave Macmillan.

Roberts Brian. 2015. Biographical research: Past, present, future. In: Advances in biographical methods, M.'Neill, B. Roberts, A. Sparkes (eds.), 11-30. Abingdon Oxon: Routledge.

Rosa Hartmut. 2019. Resonance. A sociology of the relationship to the world. trans. J. Wagner, Cambridge: Polity.

Scheff Thomas. 2006. Silence and mobilization: Emotional/relational dynamics. Human dignity and humiliation studies. www.humiliationstudies.org/documents/ScheffSilenceandMobilization.pdf, [accessed 18.10.2015].

Schütze Fritz. 1992. "Pressure and guilt: War experiences of a young German soldier and their biographical implications". International Sociology II(2): 187-208; II(3): 347-367.

Smith Phil. 2010. Mythogeography. Axminster, UK: Triarchy Press.

Smith Phil. 2015. Walking's new movement. Axminster, UK: Triarchy Press.

Solnit Rebecca. 2001. Wanderlust: A history of walking. London: Verso.

Sparkes Andrew. 2004. "Bodies, narratives, selves and autobiography: The example of Lance Armstrong". Journal of Sport and Social Issues 28(4):397-428.

Sparkes Andrew. 2015. When Bodies need stories: Dialogical narrative analysis in action. In: Advances in Biographical Methods, M. O’Neill, B. Roberts, A. Sparkes (eds.), 30-43. Abingdon, Oxon: Routledge.

Thorne Brian. 1992. Carl Rogers. London: Sage Publications.

Thomas William I., Florian Znaniecki. 1958. The Polish peasant in Europe and America. 2 ols. New York: Dover Press (first pub. 1918-20).

Urry John. 2007. Mobilities. Cambridge: Polity.

Weigel Sigrid Z. 1996. Body- and image-space: Re-reading Walter Benjamin. trans. G. Paul, R. McNicholl, J. Gaines, London: Routledge.

Wengraf Tom 2001. Qualitative research interviewing. Biographical narrative and semi-structured methods. London: Sage

Witkin Robert W. 1974. The intelligence of feeling. London: Heineman.

Ylijoki Oili-Helena. 2011. "Boundary-work between work and life in the high-speed university". Studies in Higher Education 2011(2).

Maggie O'Neill

\section{BADANIA BIOGRAFICZNE W RUCHU: TEORETYZOWANIE, DOŚWIADCZANIE, WYOBRAŻENIE (SZKOLA CHICAGOWSKA - REINTERPRETACJA)}

\section{Streszczenie}

W artykule zbadano znaczenie spacerowania w metodach biograficznych i krytycznie rozważono jego teoretyczne, doświadczalne i wyobrażeniowe zastosowanie 100 lat po publikacji Chłopa polskiego w Europie i Ameryce. Tym samym stawiam pytanie, w jaki sposób chodzenie jako ,artystycznie ugruntowane" podejście do prowadzenia badań biograficznych może przyczynić się do stworzenia warunków sprzyjających dobrostanowi ludzi, ponownej etyzacji badań społecznych i krytycznego podejścia do patologii społecznych? Odpowiadając na to pytanie, skupiam się na 
znaczeniu teorii krytycznej i socjologii biograficznej w rozumieniu biografii i historii oraz proponuję, aby doświadczenie chodzenia z innym, prowadzenia WIBM (Walking Interview Biographical Method - metoda wywiadu biograficznego podczas spaceru), otwierało możliwość dialogu, słuchania jako rozumienia, „rezonansu”, a także budziło zaufanie i potencjał solidarności, jako część etyki słuchania. Czyniąc to, musimy jednak pamiętać o etycznych implikacjach WIBM. Przykłady z wywiadów biograficznych podczas spaceru ilustrują tę kwestie.

Słowa kluczowe: Chłop polski w Europie i Ameryce, spacerowanie, WIBM, socjologia biograficzna, szkoła chicagowska 